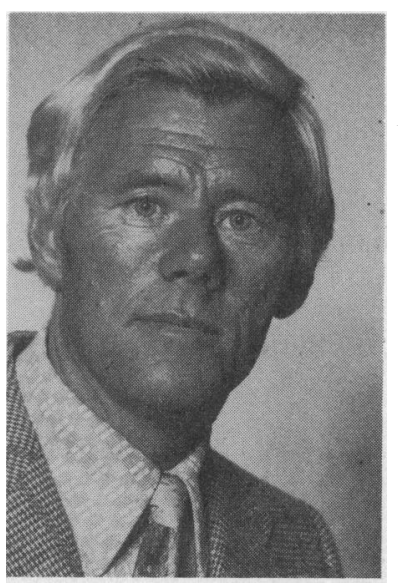

\title{
PRE- AND POST-ADOLESCENTS' PHYSIOLOGICAL RESPONSE TO EXERCISE
}

\author{
P. BALE, MIBiol., DipEd., MBPS, PhD
}

Senior Lecturer, Chelsea School of Human Movement, Brighton Polytechnic \begin{abstract}
influential to performance during growth at adolescence.
\section{INTRODUCTION}

An initial investigation of fifty eleven year old school children (Bale, 1978) emphasised the similarity in performance between the sexes at this age. As Table I illustrates, there is little difference between the boys and girls in their physiological performance in response to exercise. When $\mathrm{VO}_{2}$ max was related to body weight the small difference that accrued between the boys and girls was further reduced, suggesting that weight not sex is the most important determinant of performance at this age. As Table II indicates, weight and also height correlated significantly with $\mathrm{VO}_{2} \max , \mathrm{V}_{\mathrm{E}} \max$ and physical work capacity.
\end{abstract}

ABSTRACT

The physiological performance of a group of boys and girls aged eleven to twelve years was examined and nineteen of these children were retested again at aged sixteen years. The findings of this investigation support the findings of other similar studies that, when $\mathrm{VO}_{2}$ max is used as a determinant of cardiovascular performance, the performance of children increases with age, and in boys particularly, this increase is associated with an increase in body weight. After puberty boys have a greater oxygen consumption and thus a greater physiological performance than girls, mainly as a result of an improved cardiorespiratory efficiency and a greater muscle to weight ratio. The improvement in their physiological performance by those girls particularly interested in sport, however, also suggests that this factor is most

\section{METHOD}

Nineteen of the children tested at eleven years, ten boys and nine girls, returned to the laboratory to be retested at aged sixteen years. The children were volunteers from two local schools and were already familiar with the test equipment. As in the earlier study, parental permission and medical clearance were obtained.

Initially height and weight were measured. Each child then rested for fifteen minutes and heart rate and blood pressure were recorded during the last minute of this period. As the progressive exercise test using a constant pedal rate cycle ergometer, proved to be most satis-

\section{TABLE I}

The physiological performance in relation to exercise of 11 year old schoolchildren.

\begin{tabular}{|c|c|c|c|c|c|c|c|c|c|c|c|c|}
\hline Subjects & $\begin{array}{l}\text { Age } \\
\text { (years) }\end{array}$ & $\begin{array}{l}\text { Weight } \\
\text { kg }\end{array}$ & $\begin{array}{l}\text { Height } \\
\mathrm{cm}\end{array}$ & $\begin{array}{l}\text { Heart } \\
\text { Rate } \\
\text { beat } \\
\min ^{-1}\end{array}$ & $\begin{array}{l}\mathrm{VO}_{2} \max ^{-1} \\
\mathrm{~L} \min ^{-1} \\
\text { STPD }\end{array}$ & $\begin{array}{l}\mathrm{VO}_{2} \max _{-1} \\
\mathrm{ml} \mathrm{kg}^{-1} \\
\min ^{-1} \\
\text { STPD }\end{array}$ & $\begin{array}{l}\dot{V}_{E} \max \\
L \min ^{-1} \\
B T P S\end{array}$ & $\begin{array}{l}V_{E} \max \\
m^{-1} k^{-1} \\
\min ^{-1} \\
\text { BTPS }\end{array}$ & $\begin{array}{l}\text { Ventilation } \\
\text { per litre } \\
\mathrm{VO}_{2}\left\llcorner\min ^{-1}\right.\end{array}$ & $\begin{array}{l}\text { Max } \mathrm{O}_{2} \\
\text { Pulse }\end{array}$ & $\begin{array}{l}\text { Max } \\
\text { Systolic } \\
\text { BP } \\
\mathrm{mm} \mathrm{Hg}\end{array}$ & $\begin{array}{l}P_{170} \\
\text { mkp min }^{-1}\end{array}$ \\
\hline Girls m & 11.47 & 38.0 & 146.8 & 197 & 1.48 & 38.94 & 50.8 & 133.7 & 35.3 & 7.5 & 139.5 & 650 \\
\hline$N=25 S . D$. & 0.31 & 6.2 & 5.1 & 5.3 & 0.32 & 6.6 & 7.7 & 21.6 & 7.2 & 1.7 & 12.8 & 63.1 \\
\hline Boys m & 11.45 & 41.23 & 147.8 & 193 & 1.65 & 40.01 & 57.6 & 139.7 & 35.5 & 10.7 & 137.7 & 720 \\
\hline$N=25 S . D$. & 0.34 & 9.4 & 6.1 & 7.1 & 0.32 & 6.8 & 8.8 & 22.7 & 4.8 & 10.0 & 8.7 & 120.2 \\
\hline
\end{tabular}




\section{TABLE II}

The relationship between weight and height and the physiological variables of fifty eleven year old's.

\begin{tabular}{lcc} 
& \multicolumn{2}{c}{ Physique Variables } \\
Physio Var. & Weight & Height \\
Heart Rate & -0.21 & -0.03 \\
$\mathrm{VO}_{2} \max$ & 0.68 & 0.35 \\
& $* *$ & $* *$ \\
$\mathrm{~V}_{\mathrm{E}} \max$ & 0.64 & 0.31 \\
& $* *$ & $*$ \\
Max Systolic & & \\
Blood Pressure & 0.16 & 0.09 \\
PWC 170 & 0.45 & 0.43 \\
& $* *$ & $* *$ \\
Significance levels of Product moment correlations \\
* Significant at $\mathrm{P}<.05$ \\
* Significant at $P<.01$
\end{tabular}

factory for studying maximum exercise when the children were tested at eleven years, this was repeated at sixteen years. Each subject performed a short warmup exercise on the ergometer during which individual adjustments to the pedals, handle bars and saddle height were made. The test began at an initial load of 300 $\mathrm{mkp}$ at $60 \mathrm{rev} / \mathrm{min}$. Resistance was progressively increased until the subject was unable to continue or the pedal rate dropped below $50 \mathrm{rev} / \mathrm{min}$. Throughout the test the experimentor provided assurance and encouraged each child to continue cycling beyond the point where they would have preferred to stop in order to determine maximum oxygen consumption. The criteria for $\mathrm{VO}_{2}$ max was maximum heart rate for sixteen years at the point of the subject's feeling of exhaustion.
Expired air was collected, using a face mask (BOC) and passed through a dry gas meter (Parkinson-Cowan). Gas temperature was recorded continuously and all ventilations were converted to BTPS. Oxygen analysis was made using a paramagnetic analyser (servomex) calibrated prior to and following each test, using cylinders of standard gas. All reported $\mathrm{VO}_{2}$ 's were expressed at STPD. Cardiac frequency was monitored throughout the exercise and in recovery, using bipolar chest electrodes in conjunction with an ECG Amplifier and pen recorder. In addition blood pressure was taken at the end of exercise and during recovery, using a cuff sphygmomanometer.

Work capacity was calculated by plotting heart rate against work load and the estimated amount of work that produced a heart rate of 170 beats $/ \mathrm{min}$ was recorded as the physical work capacity (PWC 170 ). This is approximately $80 \%$ of absolute work capacity. $\mathrm{O}_{2}$ pulse was also calculated from Max $\mathrm{HR}$ and $\mathrm{VO}_{2}$ max, and ventilatory equivalent from $V E$ max and $\mathrm{VO}_{2}$ max.

The t-test was used to test for significance between performance at 11 and 16 years and between the boys and girls at 16 years. Only $P$ values less than 0.05 were regarded as significant.

\section{RESULTS AND DISCUSSION}

A comparison between the performance of the children at 16 years is presented in Table III and between the boys and girls at eleven and sixteen in Table IV.

When $\mathrm{VO}_{2} \max$ is considered in absolute terms, the performance of the girls fell well below that of the boys. Comparison of the relative aerobic power expressed as $\mathrm{VO}_{2}$ max per $\mathrm{kg}$ body weight between the

\section{TABLE III}

Comparison between the boys and girls at sixteen years.

\begin{tabular}{|c|c|c|c|c|c|c|c|c|c|c|c|c|}
\hline Subjects & $\begin{array}{l}\text { Age } \\
\text { (years) }\end{array}$ & $\begin{array}{l}\text { Weight } \\
\text { kg }\end{array}$ & $\begin{array}{l}\text { Height } \\
\mathrm{cm}\end{array}$ & $\begin{array}{l}\text { Heart } \\
\text { Rate } \\
\text { beat } \\
\text { min }^{-1}\end{array}$ & $\begin{array}{l}\mathrm{VO}_{2} \max \\
\mathrm{Lmin}^{-1} \\
\text { STPD }\end{array}$ & $\begin{array}{l}\mathrm{VO}_{2} \max ^{-1} \\
\mathrm{ml} \mathrm{kg}^{-1} \\
\min ^{-1} \\
\text { STPD }\end{array}$ & $\begin{array}{l}V_{E} \max \\
L \text { min }^{-1} \\
\text { BTPS }\end{array}$ & $\begin{array}{l}V_{E} \max ^{-1} \\
\mathrm{mi} \mathrm{kg}^{-1} \\
\min ^{-1} \\
\text { BTPS }\end{array}$ & $\begin{array}{l}\text { Ventilation } \\
\text { per litre } \\
\mathrm{VO}_{2}\left\llcorner\min ^{-1}\right.\end{array}$ & $\begin{array}{l}\text { Max } \mathrm{O}_{2} \\
\text { Pulse }\end{array}$ & $\begin{array}{l}\text { Max } \\
\text { Systolic } \\
\text { BP } \\
\mathrm{mm} \mathrm{Hg}\end{array}$ & $\begin{array}{l}P^{P W C_{170}} \\
\text { mkp min }\end{array}$ \\
\hline Girls m & 15.9 & 47.98 & 155.8 & 195 & 1.67 & 35.3 & 58.2 & 122 & 34.8 & 8.6 & 158.9 & 683 \\
\hline$N=9$ S.D. & .27 & 4.1 & 4.0 & 3.7 & .29 & 8.1 & 12.8 & 28.1 & 4.8 & 1.5 & 8.1 & 87.5 \\
\hline Boys m & 15.9 & 55.27 & 167.1 & 194 & 2.34 & 42.8 & 69.3 & 127 & 29.6 & 12.1 & 159 & 853 \\
\hline$N=10$ S.D. & .25 & 9.0 & 8.8 & 9.8 & .42 & 7.4 & 14.3 & 28.6 & 4.3 & 2.2 & 5.9 & 82.8 \\
\hline $\begin{array}{l}t \text { value } \\
\text { Significance }\end{array}$ & & $\begin{array}{c}2.31 \\
*\end{array}$ & $\begin{array}{l}3.62 \\
* *\end{array}$ & 0.33 & $\underset{* *}{4.12}$ & $\begin{array}{c}2.12 \\
*\end{array}$ & 1.78 & 0.38 & $\begin{array}{c}2.48 \\
*\end{array}$ & $\begin{array}{l}4.07 \\
* *\end{array}$ & .03 & $\begin{array}{l}4.31 \\
* *\end{array}$ \\
\hline
\end{tabular}

Significance levels

* Significant at $P<.05$

* * Significant at $P<.01$ 
children at eleven and at sixteen years further emphasises the superiority of the boys at this age. Indeed $\mathrm{VO}_{2}$ max per $\mathrm{kg}$ body weight in the girls was below the level achieved at eleven years.

The major cause of differences at sixteen can be attributed to the structural and physiological changes that occur at adolescence. Astrand (1952) and Godfrey et al (1971) for example, have reported a high relationship between $\mathrm{VO}_{2}$ max and body weight in non-obese boys compared with that of girls of similar age. Though older girls have approximately the same $\max \mathrm{VO}_{2}$ per $\mathrm{kg}$ of lean body weight as boys, the higher percent fat and lower oxygen carrying capacity of girls contributes to the differences between the sexes. When Davies et al (1972) related $\mathrm{VO}_{2}$ max to leg muscle volume for example, the relationship was linear and the sex difference disappeared.

As a consequence of boys' greater lung capacity, pulmonary ventilation increases while respiratory rate drops with age, (Tanner, 1969). Similarly $V_{E} \max$ was higher in the children at sixteen in this study. The ventilation required for each litre of oxygen utilised is considerably lower in the boys at adolescence than the girls, and this greater respiratory efficiency is further supported by their higher oxygen pulse.

Systolic blood pressure at rest and maximum systolic pressure at the end of exercise was highest at sixteen years in both boys and girls. Other investigators have obtained increased maximum systolic blood pressures in older boys after exercise but not in girls. The eleven year olds showed a greater fall in diastolic blood pressure after exercise which, as Shock (1966) comments, may be because the arteries of young adults undergo less relaxation than those of children. The blood pressures of the sixteen year olds also took longer to return to their resting level. The resting heart rate and heart rate at submaximal levels of exercise decreased with age but maximum heart rate at sixteen did not vary significantly for either sex. As with systolic blood pressure, heart rate, oxygen consumption and pulmonary ventilation returned to their resting levels quicker in the eleven year olds than in the adolescents. A review of the literature on growth and development indicates that boys at adolescence experience an increase in haemoglobin and red blood cells and an enlarged blood volume not evidenced by girls. They also develop larger hearts and consequently a greater stroke volume. These structural

\section{TABLE IV}

\section{Comparison between the girls at 11 and at 16 years and between the boys at 11 and 16 years.}

\begin{tabular}{|c|c|c|c|c|c|c|c|c|c|c|c|c|}
\hline Subjects & $\begin{array}{l}\text { Age } \\
\text { (years) }\end{array}$ & $\begin{array}{l}\text { Weight } \\
\text { kg }\end{array}$ & $\begin{array}{l}\text { Height } \\
\mathrm{cm}\end{array}$ & $\begin{array}{l}\text { Heart } \\
\text { Rate } \\
\text { beat } \\
\min ^{-1}\end{array}$ & $\begin{array}{l}\mathrm{VO}_{2} \max \\
\mathrm{Lmin}^{-1} \\
\text { STPD }\end{array}$ & $\begin{array}{l}\mathrm{VO}_{2} \max _{-1} \\
\mathrm{ml} \mathrm{kg}^{-1} \\
\min ^{-1} \\
\text { STPD }\end{array}$ & $\begin{array}{l}V_{E \max } \\
L \min ^{-1} \\
\text { BTPS }\end{array}$ & $\begin{array}{l}V_{E} \max ^{-1} \\
\mathrm{ml} \mathrm{kg}^{-1} \\
\min ^{-1} \\
\text { BTPS }\end{array}$ & $\begin{array}{l}\text { Ventilation } \\
\text { per litre } \\
\mathrm{VO}_{2}\left\llcorner\mathrm{~min}^{-1}\right.\end{array}$ & $\begin{array}{l}\text { Max } \mathrm{O}_{2} \\
\text { Pulse }\end{array}$ & $\begin{array}{l}\text { Max } \\
\text { Systolic } \\
\text { BP } \\
\mathrm{mm} \mathrm{Hg}\end{array}$ & $\begin{array}{l}P_{170} \\
\text { mkp min }^{-1}\end{array}$ \\
\hline & 11.5 & 37.90 & 143.8 & 197 & 1.47 & 38.8 & 52.4 & 139.9 & 36.6 & 7.4 & 139.4 & 642 \\
\hline Girls & .29 & 6.4 & 5.5 & 5.5 & .25 & 6.3 & 5.3 & 15.6 & 7.1 & 1.4 & 7.5 & 46.8 \\
\hline$N=9$ & $\begin{array}{r}15.9 \\
.27\end{array}$ & $\begin{array}{c}47.98 \\
4.1\end{array}$ & $\begin{array}{r}155.8 \\
4.0\end{array}$ & $\begin{array}{r}195 \\
3.7\end{array}$ & $\begin{array}{r}1.67 \\
.29\end{array}$ & $\begin{array}{r}35.3 \\
8.1\end{array}$ & $\begin{array}{l}58.2 \\
12.8\end{array}$ & $\begin{array}{r}121.9 \\
28.1\end{array}$ & $\begin{array}{r}34.8 \\
4.8\end{array}$ & $\begin{array}{l}8.6 \\
1.5\end{array}$ & $\begin{array}{r}158.9 \\
8.1\end{array}$ & $\begin{array}{l}683 \\
87.5\end{array}$ \\
\hline $\begin{array}{l}t \text { value for } \\
\text { paired } \\
\text { samples } \\
\text { significanc }\end{array}$ & & ** & ** & 1.60 & 1.72 & 1.80 & 1.48 & 2.30 & 0.97 & 1.93 & 4.3 & 1.26 \\
\hline Boys & $\begin{array}{r}11.4 \\
.37\end{array}$ & $\begin{array}{c}40.95 \\
8.0\end{array}$ & $\begin{array}{r}146.1 \\
2.9\end{array}$ & $\begin{array}{r}193 \\
6.5\end{array}$ & $\begin{array}{r}1.60 \\
.21\end{array}$ & $\begin{array}{c}39.84 \\
5.7\end{array}$ & $\begin{array}{r}55.8 \\
7.1\end{array}$ & $\begin{array}{r}138.4 \\
16.4\end{array}$ & $\begin{array}{r}34.9 \\
2.9\end{array}$ & $\begin{array}{l}8.3 \\
1.1\end{array}$ & $\begin{array}{r}139.1 \\
9.9\end{array}$ & $\begin{array}{r}722.5 \\
79.5\end{array}$ \\
\hline$N=10$ & $\begin{array}{r}15.9 \\
.25\end{array}$ & $\begin{array}{c}55.27 \\
9.0\end{array}$ & $\begin{array}{r}167.1 \\
8.8\end{array}$ & $\begin{array}{r}194 \\
9.8\end{array}$ & $\begin{array}{r}2.34 \\
.42\end{array}$ & $\begin{array}{r}42.8 \\
7.4\end{array}$ & $\begin{array}{l}69.3 \\
14.3\end{array}$ & $\begin{array}{r}126.9 \\
28.6\end{array}$ & $\begin{array}{r}29.6 \\
4.3\end{array}$ & $\begin{array}{r}12.1 \\
2.2\end{array}$ & $\begin{array}{r}159.0 \\
5.9\end{array}$ & $\begin{array}{r}853 \\
82.8\end{array}$ \\
\hline $\begin{array}{l}t \text { value for } \\
\text { paired } \\
\text { samples } \\
\text { significano }\end{array}$ & & 7.06 & ** & 0.40 & * * & 1.42 & 2.84 & 1.56 & 3.80 & ** & 6.58 & ** \\
\hline
\end{tabular}


and physiological changes at adolescence result in a greater efficiency in the uptake and transport of oxygen in boys, with the result that they are more able to work at higher work rates over longer periods than girls. They have a greater physical work capacity, as shown by the mean PWC 170 of 853 mkp min compared with 683 mkp min achieved by the girls at sixteen, which was only $41 \mathrm{mkp}$ min higher than that achieved at eleven years.

In contrast to the general findings, three of the girls retested at sixteen, who showed considerable interest and participation in sport, had improved their physiological performance in response to exercise even when this response was related to kilograms of body weight. A finding which sungests that, though the biological changes at adolescence $a_{1} e$ of major importance, interest and participation in sport at this age are also influential.

Though the physiological requirements of exercise are understood, the nature of the physiological response is complex. Clearly the demand for oxygen by the active muscles is influenced by the amount of exercise performed and this demand is met in part by an increase in such cardiorespiratory factors as heart rate ind pulmonary ventilation. In addition other aspects of physiological growth are involved. Individual difference in response to exercise therefore, may also depend upon the interrelation between these physiological parameters and the degree of participation in physical education and sport.

Recent studies on the effect of training on physical performance, particularly of teenage boys, suggest that improvement occurs in $\mathrm{VO}_{2}$ max by between $14-20 \%$ (Macek et al, 1976; Placheta et al, 1980; Renson, 1971: Venfraechem and Vanfraechem, 1978). This rise in $\mathrm{VO}_{2}$ max is accompanied by improvement in other physiological parameters such as stroke volume and oxygen pulse. In Placheta's longitudinal study of 12-15 year old boys, training particularly for endurance, significantly lowered heart rate in response to work loads of submaximal intensity below that expected as a result of increased age.

Godfrey (1974) in a review of the effects of physical training concluded that the improvements which occur in children after training are similar to those seen in adults. He also adds that these changes do not occur as a result of routine PE in schools, however strenuous. The present findings support this conclusion but suggest that girls as well as boys can improve in performance as a result of increased physical activity during growth at adolescence.

\section{REFERENCES}

Åstrand, P. O., 1975. Experimental studies of physical working capacity in relation to sex and age. E. Munksgaard, Copenhagen.

Bale, P., 1978 "The physiological performance of pre-adolescent school children". Physical Education Review 1: 89-95.

Davies, C. T. M., Barnes, C. and Godfrey, S., 1972 "Body composition and maximal exercise performance in children". Human Biology 44: 195-214.

Godfrey, S., 1974 "The growth and development of the cardio-pulmonary responses to exercise". In J. Davis and J. Dobbing (eds.) Scientific Foundations of Paediatrics, Heinemann.

Godfrey, S., Davies, C. T. M., Wozniak, E. and Barnes, C. A., 1971 "Cardiorespiratory responses to exercise in normal children". Clinical Science 40: 419-431.

Macek, M., Vavra, J. and Novosadova, J., 1976 "Prolonged exercise in prepubertal boys". Journal of Applied Physiology 35: 291-298.

Placheta, Z. (Ed.), 1980 "Youth and physical activity". J. E. Purkyne Univ. Brno, Czechoslovakia.

Renson, R., 1971 “Comparison of athletes versus non-athletes among Belgian secondary school boys aged 12 to 19 ". Journal of Sports Med. \& Physical Fitness 11: 213-221.

Shock, N. A. and Falkner, F., 1966 "Human development". Saunders \& Co.

Tanner, J. M., 1978 "Foetus into Man". Open Books.

Vanfraechem, J. and Vanfraechem-Raway, R., 1978 "The influence of training upon physiological and psychological parameters in young athletes". Journal of Sports Medicine \& Physical Fitness 18: 175-182. 